\title{
Developing Green Finance to Promote the Development of New Agricultural Business Entities
}

\author{
Minfeng Lin ${ }^{1}$, Mei Qiang ${ }^{2, *}$ \\ ${ }^{1}$ School of Management, Jiangsu University Zhenjiang, China \\ ${ }^{2}$ School of Management, Jiangsu University Zhenjiang, China
}

\begin{abstract}
The Chinese government is paying attention to the development of new agricultural business entities and improving green finance is a key to achieve the goal of rural revitalization. The study depends on both primary analysis based on semi-structured interviews and secondary analysis obtained from government reports, annual reports, published articles and academic papers to find out what can be learned from the experience in the UK. From analysis, this study found three major lessons that can be learned from the UK's practice, including to develop a proper green financial regulatory system, to build a more mature market transaction system and to construct a more transparent green information sharing platform. Besides, the commercial banks in China need to deal with four challenges in the process of expanding green finance.
\end{abstract}

\section{Introduction}

In recent years, China has paid an increasing attention to the cultivation and development of new agricultural business entities. Due to the natural weak nature of agriculture, imperfect credit system and other reasons, most agricultural operators face financing difficulties. To this end, the Chinese government has tried various methods and it has been found that to set up green finance is an important method. Green finance is a broad term which can refer to financial investments flowing to sustainable development projects and initiatives, policies and environmental services and products that encourage the development of a more sustainable economy.

Green finance covers various services and products targeted at different demands. In this study, green credit is the primary research focus, which accounts for a large proportion of green finance in Chinese market, where green credit refers to credit that banks grant for projects with low environmental risks.

The characteristics of the new agricultural business entities are larger scale, more scientific production process, and more emphasis on greening. These characteristics will make them directly benefit from the development of green finance. Therefore, the Chinese government is paying more and more attention to the development of green finance, and in China, green credit accounts for more than 90 per cent of green finance, the other 10 per cent covers green bonds, green insurance, green funds. Taking the proper solutions to better develop green credit makes sense in the process of pursuing sustainable agricultural development in China.

The UK has taken a leading position in promoting green finance and its sustainable fund management sector is already Europe's largest [1]. Therefore, it can be expected that there to be some valuable lessons that can be applied in the Chinese context from the experience of promoting green finance in the UK.

\section{The benefits of developing green credit}

\subsection{Benefits of green credit on the economic dimension}

Using the Equatorial Principles to assess the projects, commercial banks have reduced the overall risk of decision-making. Cui et al. [2] collected data from several different Chinese banks and used regression analysis, and the findings showed that banks with a higher percentage of green loans are associated with a better performance of loans repayment.

Also, green credit is a way for commercial banks and corporates to take their social responsibility, which will improve their reputation. Dell'Atti et al. [3] found that corporate social responsibility engagement is important to the formation of reputation, and corporate reputation has a positive correlation with corporate economic performance.

Furthermore, some scholars argue that green credit can promote high-quality economic development through an ecological improvement effect. Plumlee et al. [4] first constructed an environmental information disclosure index which reflects the quality of the ecological information disclosure. Further, an empirical analysis of the relationship between the index and financing costs has been conducted, and the results show that the higher quality of the information disclosed, the less financial costs will be.

*Corresponding author. Email: qmei@ujs.edu.cn 


\subsection{Benefits of green credit on the social dimension}

Green credit can be seen as a special type of subsidy mode, and some scholars found that the amount of bank loan will affect the relative validity of different modes. Huang et al. [5] concluded that when bank loans are infinite, and the total amount of subsidies of other modes are equal, green credit can bring the highest returns in terms of social welfare, market demand, and environmental benefits.

By creating a green financial system, it can effectively lead social capital to support the development of environmental-friendly industries, which will benefit to the social welfare indirectly [6]. For example, Hu et al. [7] used theoretical analysis to find out that green credit can guide the transformation and upgrading of industries by promoting mergers and restructuring of different sectors, and this will improve the social welfare by improving the environment of industries and the quality of service and product provided [8].

\subsection{Benefits of green credit on the environmental dimension}

Some researchers believe that environmental and energy problems should be tackled at the level of the country and that developing green credit is a key solution to severe ecological problems [9]. In order to win competitive advantage, enterprises not only need to carry out traditional corporate innovation activities but to take ecological innovation into their development plan because ecological innovation can reduce the adverse impact of the organization on the natural environment and improve the internal efficiency of the corporate as well [10]. To maximize the efficiency of renewable energy investment on the sustainable economy, it is crucial to combine the green credit policy issued by the government and concrete measures of the financial institutions. Furthermore, it has been proved that the correlation between corporate information disclosure associated with environmental protection and actual environmental performance is positive [11].

\section{Method}

\subsection{Data collection}

To gain a better insight into the benefits and challenges of developing green credit, semi-structured interviews were conducted with five managers in three banks -- Bank of China, Industrial Bank and Rural Commercial Bank. Besides, four front office employees working in these three banks stated above, six employees who work in Chang'an Bank (a local joint-stock bank) and three employees who work in Shanghai Pudong Development Bank (a national joint-stock bank) were also contacted, but all of them stated that they have little knowledge about green finance. In addition to interviews, the annual reports, ESG reports and the work of some researchers relating to green finance in the Chinese market, have also been collected as data for further analysis.
Each interviewee was asked eight questions to clarify their role and expertise in relation to green credit, and their ideas on what support can help banks to better conduct green credit and improve the performance of green credit in China. A total of five respondents participated in the one-to-one interviews, and their basic background information and case ID is summarized in Table 1.

Table1. The basic information of interviewees.

\begin{tabular}{|l|l|l|l|}
\hline Interviewees Bank & Delegate Role & City & Case ID \\
\hline \multirow{5}{*}{ Bank of China } & $\begin{array}{l}\text { Manager of Enterprise Loans Business } \\
\text { Department }\end{array}$ & X'an (provincial capital city) & C1 \\
\cline { 2 - 4 } & $\begin{array}{l}\text { Manager of Personal Loans Business } \\
\text { Department }\end{array}$ & X'an (provincial capital city) & $\mathrm{C2}$ \\
\cline { 2 - 4 } & Department Manager & Zhenjiang (prefecture level city) & $\mathrm{C3}$ \\
\hline Industrial Bank & Department Manager & Fuzhou (provincial capital city) & $\mathrm{C4}$ \\
\hline Rural Commercial Bank & Director of Planning and Development & Shenyang (provincial capital city) & C5 \\
\hline
\end{tabular}

\subsection{Data analysis}

After getting the interviews done, the author transcribed all the data collected and classified the data to six topics, including positive opinions, negative opinions, development plans, regulatory framework and policy, challenges, and support required. Then, the author compared the responses from different interviewees regarding the same questions and categorized them into different themes. In addition, information from the annual reports and ESG reports of banks interviewed and studies of some scholars were also classified as the six themes stated above.

\section{FINDINGS}

\subsection{The lessons from the experience of developing green finance in the UK}

The Financial Conduct Authority regulates the financial services industry in the UK and works with HM Treasury, the government's economic and finance ministry. While in China, the CBRC supervises the behavior of banks, and the Environmental Protection Agency (EPA) supervises the behavior of green enterprises. The lack of cooperation between the CBRC and the EPA has led to the inefficiency of the green financial regulatory system. In July 2019, the British government proposed the Green Finance Strategy, and Figure 1 shows the key elements of each strategy.

\begin{tabular}{|c|c|c|}
\hline Strategy & Key Elements of The Strategy & Strategy ID \\
\hline \multirow{4}{*}{ Greening Finance } & 1) Establishing a shared understanding & S-1-1 \\
\hline & 2) Claritying the roles and responsibilities of various departments & s-1-2 \\
\hline & 3) Fostering transparency and embedding along-term approach & S-1-3 \\
\hline & 4) Buiding robust and consistent greenfinancial market frameworks & S-1-4 \\
\hline \multirow{4}{*}{ Financing Green } & 1) Establishing robust, long-term policytrameworks & S-2-1 \\
\hline & 2) Improving access to finance for greeninvestment & S-2-2 \\
\hline & 3) Addressing market barriers and buildingcapability & S-2.3 \\
\hline & 4) Developing innovative approaches and newways of working & S-2-4 \\
\hline \multirow{3}{*}{ Capturing the Opportunity } & 1) Consolicating the UK's position as a globalhub for green finance & S-3-1 \\
\hline & 2) Postioning the UK at the foreffront of greenfinancial innovation and data and analytics & S-3-2 \\
\hline & 3) Building skills and capabilities on greenfinance & S-3.3. \\
\hline
\end{tabular}

Figure 1 The content of the strategy

It is true that the transformation to the green economy is challenging because it has to face conflicts of interest between different departments, localities, and industries, and even the embarrassment between the public's high 
expectations and imperfect results [12]. According to the interviews and secondary research, there are three lessons that can be learnt from the practice of expanding green finance in the UK, as set out in Figure 2.

It is interesting that all interviewees emphasized the importance of equal access to information. Banks in the UK market attach great significance to publishing their corporate social responsibility reports on time while most commercial banks in China still regard green finance as a political product. A large space in banks' website has been used to illustrate the benefits of green finance, but there is no clear guidance for the public to find out what banks have done and what they have achieved in the sector of green finance.

Based on the sharing of respondents, it can be found that a more transparent information sharing platform can help the general public better to understand the role of green finance (C5), help the loan applicant know how they qualify their projects to meet the provision of credits (C4), and help the regulators to oversee the flow of funds in the green finance part of the bank (C2).

\begin{tabular}{|c|c|c|}
\hline & \multicolumn{2}{|c|}{ Detail Description Evidence from Interviews or Secondary Research } \\
\hline \multirow{5}{*}{$\begin{array}{l}\text { Lesson 1: } \\
\text { developing a } \\
\text { green financial } \\
\text { regulatory system }\end{array}$} & \multirow{5}{*}{$\begin{array}{l}\text { The role of the } \\
\text { regulatory system } \\
\text { includes protecting } \\
\text { consumers, keeping } \\
\text { the industry stable, } \\
\text { and promoting healthy } \\
\text { competition between } \\
\text { financial service } \\
\text { providers }\end{array}$} & $\begin{array}{l}\text { "A good regulatory system can ensure that when problems arise, market participants } \\
\text { know which subject should shoulder the responsibilty and what kind of support they } \\
\text { can ask for, so as to prevent the same problems appearing from time to time"-C1 }\end{array}$ \\
\hline & & $\begin{array}{l}\text { The effectiveness of the regulatory system largely determines whether the flow of } \\
\text { green credit funds meets the expected goals"--C3 }\end{array}$ \\
\hline & & S-1-2 (Green Finance Strategy 2019) \\
\hline & & S-2-1 (Green Finance Strategy 2019) \\
\hline & & S-2.3 (Green Finance Strategy 2019) \\
\hline \multirow{7}{*}{$\begin{array}{l}\text { Lesson 2: building } \\
\text { a more mature } \\
\text { market } \\
\text { transaction } \\
\text { system }\end{array}$} & \multirow{7}{*}{$\begin{array}{l}\text { A comprehensive } \\
\text { trading system } \\
\text { includes richer } \\
\text { financial products and } \\
\text { more mature trading } \\
\text { methods, meeting } \\
\text { various demand from } \\
\text { clients }\end{array}$} & $\begin{array}{l}\text { "Paying attention to the pertinence and diversity of products is conducive to better } \\
\text { satisfying different consumer needs"--C3 }\end{array}$ \\
\hline & & $\begin{array}{l}\text { "Different market entities such as enterprises, households, and individuals have } \\
\text { differentiated needs for financial products, and the current green financial products in } \\
\text { the Chinese market largely only focus on the needs of enterprises"--C4 }\end{array}$ \\
\hline & & $\begin{array}{l}\text { Barclays Bank launched a green fuel-saving financing product for truck drivers, a } \\
\text { product is characterized by strong pertinence and distinctive features (Barclays ESG } \\
\text { report 2019) }\end{array}$ \\
\hline & & S-14 (Green Finance Strategy 2019) \\
\hline & & S-2-2 (Green Finance Strategy 2019) \\
\hline & & S-24 (Green Finance Strategy 2019) \\
\hline & & S-3-3 (Green Finance Strategy 2019) \\
\hline \multirow{6}{*}{$\begin{array}{l}\text { Lesson 3: building } \\
\text { a more } \\
\text { transparent green } \\
\text { informatiton } \\
\text { sharing plattorm }\end{array}$} & \multirow{6}{*}{\begin{tabular}{|l} 
A information sharing \\
platform connects \\
financial institutions, \\
regulation \\
ogrganizations and \\
clients, which can \\
improve the efficiency \\
and quality of \\
decision-making by \\
these three parties
\end{tabular}} & $\begin{array}{l}\text { "A more transparent green information sharing plattorm can help improve the } \\
\text { operational efficiency of financial institutions and enhance their autonomy in } \\
\text { developing green financial products"--C1 }\end{array}$ \\
\hline & & $\begin{array}{l}\text { We should establish a system and improce the quality of information disclosure. } \\
\text { The accuracy and comprehensiveness of related information disclosure will directly } \\
\text { affect the efficiency and results of financial supenision"-C2 }\end{array}$ \\
\hline & & $\begin{array}{l}\text { It is somewhat dificult for customers to find exact figures about what the bank have } \\
\text { achieved in the sector of green finance"--C5 }\end{array}$ \\
\hline & & $\begin{array}{l}\text { HSBC set a pledge to provide S100bn of sustainable financing and investment by } \\
\text { 2025, and they show how much they have delieved in their website every year (HSBC } \\
\text { ESG Update 2019) }\end{array}$ \\
\hline & & S-1-1 (Green Finance Strategy 2019) \\
\hline & & S-1.3 (Green Finance Strategy 2019) \\
\hline
\end{tabular}

Figure 2 The content of lessons

\subsection{The challenges and support required in the Chinese context to expand green credit}

It has been widely accepted that a low carbon economy cannot be achieved by the government alone [13]. The challenges faced in the Chinese green finance market mentioned in the interviews and stated in some academic papers can be classified as follows.

First, China's green finance product categories and personalized financing solutions still have room for improvement. All respondents provided a common message that the existing products in the green finance market are mainly for large-scale enterprises. Still, a large proportion of enterprises aiming at environmental protection are small and medium-sized enterprises (SME), which shows that the design of financing products ignores the characteristics of financing objects to some extent.

Second, a respondent (C3) explained that the financing scale of government-participated or government-led projects is large, while the financing scale of small and medium-sized environmental protection corporates is small. Similarly, the interviewee (C4) explained that the unbalanced allocation of financing resources has largely restricted the development of SME and has further exacerbated their financing difficulties.

Third, the participation of financial institutions is not enough. Respondents (C3 and $\mathrm{C} 5$ ) believe that the payback period of green investment is relatively long and the return during the period is relatively low and unstable, and all these factors result to the risk of green credit being higher than other credits. Besides, all interviewees agreed that even though the Chinese government encourages banks to grant green finance and issue some principles and documents to guide the development of finance, the profitability is still the priority of banks when they face the requirements of applying for loans.

Fourth, a good information sharing system has not yet been established, and some banks have a negative attitude towards responding to public information disclosure needs Based on the discussions with these employees, an interesting phenomenon emerged. 13 out of the total 18 potential interviewees said that they have not dealt with any business related to green finance, of which ten employees stated that they have not even heard of green credit before. It seems that some commercial banks in China are engaging in greenwashing activities, which means more money or time has been spent on advertising being "green" than is actually spent on environmentally sound practices. Although they spend a large amount of space to show what they have done and will do in the green finance movement on their website, it is clear that some employees do not even know what green finance is.

\section{DISCUSSION}

Both countries pay great attention to developing green finance, and the development trends are both promising. The Chinese government is always the major force in the transformation of the financial system, and the UK government has also become increasingly involved in the campaign.

In the Chinese market, the major suppliers of green finance are state-own banks, and the amount of green finance in the top five state-owned banks is more than half, while in the UK market, all banks are involved in the action. A possible reason for this situation is that the UK is a market economy, while China is a planned economy. Different economic systems mean state-owned banks have different responsibilities in the process of transition to a low-carbon economy. China's system determines that state-owned banks have a closer relationship with the government, so they will be given priority to participating in the realization of national goals and then more private banks will also join in.

Further, one of the objectives of the UK's Green Finance Strategy is to strengthen the competitiveness of 
the UK financial sector, while the government-led model in China has reduced the competition of financial players to some extent. In addition, in the practice of commercial banks in the UK, employees were found to have more voice in the development of the banks offer the plan in some way, such as the Snapshot survey in HSBC, while the employees in Chinese bank focus more on implementation.

As learned from the interview, Chinese bank branches below the provincial bank generally do not participate in the formulation of the development plan, which may cause some problems when putting the plans into practice because different cities have diverse needs for financial products. As the interview with Rural Commercial Bank has shown, the level of development of their green finance business varies in different regions. China's Northeastern region mainly develops heavy industries and has a greater demand for green credit loans. The southeast region mainly develops light industry, and traditional banks have a long history of development in these regions, so the enterprises generally apply for loans from traditional banks. Therefore, the growth of rural commercial banks' green finance business in these regions is relatively slow.

It is worth noticing that in the development plan of green finance, banks in both countries are working towards increasing their green products and service and products to attract more clients. Compared to the UK, the financial sectors in China are under less pressure to protect the environment. When an environmental problem related to a specific project arises, the media usually blames the company who run the projects or the government regulators, instead of banks and other financial sectors who provide funding to these projects. Therefore, a financial evaluation system can demonstrate the performance of bank's green finance and improve the understanding of the role of financial sectors in the development of a project and help financial bodies to take responsibility better.

Based on the interviews, there are major four challenges faced in the process of developing green finance, and the first and fourth have been mentioned in the lessons. Besides, about the problem of unbalanced allocation of financing resources, it is caused by the unreasonable design of products in China's current financial market to a certain extent. Therefore, this part mainly discusses the challenge of the limited participation of financial institutions and gives some suggestions.

All interviewees state that the payback period of environmental protection projects is longer than that of general financing projects, which increases the risk of bank lending. In addition, some innovative projects also face a great risk of project failure. Once the project fails, the bank's funds are difficult to recover. These factors have inhibited the enthusiasm of banks to provide green financial products. In response to this problem, the government can implement subsidy policies and set up corresponding institutions to help banks evaluate and supervise the implementation of projects. Although banks and other financial institutions can improve their reputation by providing green finance, they still need to obtain capital benefits from related products and services.
The problem of bank staff's insufficient understanding of green finance is largely caused by the bank's system. Employees did not participate in the formulation of the development plan, making them lack a sense of participation. In order to improve this problem, banks can place the introduction of green finance in regular training for employees. In addition, banks should strive to implement the concept of green development into the working environment of their employees. Banks can promote low carbon in their daily operations, such as promoting paperless services and actively carrying out green environmental protection activities.

\section{CONCLUSIONS}

Based on the findings of the research, it can be found that the process of developing green finance in the UK indeed provide some lessons to the Chinese financial market. About the challenges of limited green financial products, unmotivated banks and the information asymmetry, China can make efforts to develop a green financial regulatory system, build a more mature market transaction system, and construct a more transparent green information sharing platform.

Further research could choose interview samples by regions. The findings show that the development level of green finance in different areas is kind of different. However, this study only interviews with one manager from a rural commercial bank to illustrate this view, which is less convincing. It worth making a further comparison to identify how the development level of green finance change by regions in China and what are reasons for such a situation.

\section{Acknowledgment}

This work was supported by Social Science Foundation of Jiangsu Province (19JD012).

\section{References}

1. H. Simon, "How UK finance is navigating sustainability," Raconteur, Jul. 22, 2019. https://www.raconteur.net/finance/future-investing2019/uk-finance-sustainability.

2. Cui, S. Geobey, O. Weber, and H. Lin, "The Impact of Green Lending on Credit Risk in China," Sustainability, vol. 10, no. 6, p. 2008, Jun. 2018, doi: 10.3390/su10062008.

3. S. Dell'Atti, A. Trotta, A. P. Iannuzzi, and F. Demaria, "Corporate Social Responsibility Engagement as a Determinant of Bank Reputation: An Empirical Analysis," Corporate Social Responsibility and Environmental Management, vol. 24, no. 6, pp. 589605, May 2017, doi: 10.1002/csr. 1430.

4. M. Plumlee, D. Brown, R. M. Hayes, and R. S. Marshall, "Voluntary environmental disclosure quality and firm value: Further evidence," Journal of Accounting and Public Policy, vol. 34, no. 4, pp. 
336-361, Jul. 2015, doi:

10.1016/j.jaccpubpol.2015.04.004.

5. S. Huang, Z.-P. Fan, and N. Wang, "Green subsidy modes and pricing strategy in a capital-constrained supply chain," Transportation Research Part E: Logistics and Transportation Review, vol. 136, p. 101885, Apr. 2020, doi: 10.1016/j.tre.2020.101885.

6. K. Kaufer, "Social responsibility as a core business model in banking: a case study in the financial sector," Journal of Sustainable Finance \& Investment, vol. 4, no. $1, \quad$ pp. 76-89, Jan. 2014, doi: 10.1080/20430795.2014.887350.

7. Y. Hu, H. Jiang, and Z. Zhong, "Impact of green credit on industrial structure in China: theoretical mechanism and empirical analysis," Environmental Science and Pollution Research, vol. 27, no. 10, pp. 10506-10519, Jan. 2020, doi: 10.1007/s11356-02007717-4.

8. H. Chen, C. Liu, F. Xie, T. Zhang, and F. Guan, "Green Credit and Company R\&D Level: Empirical Research Based on Threshold Effects," Sustainability, vol. 11, no. 7, p. 1918, Mar. 2019, doi: 10.3390/su11071918.

9. L. He, R. Liu, Z. Zhong, D. Wang, and Y. Xia, "Can green financial development promote renewable energy investment efficiency? A consideration of bank credit," Renewable Energy, vol. 143, pp. 974984, Dec. 2019, doi: 10.1016/j.renene.2019.05.059.

10. A. F. Xavier, R. M. Naveiro, A. Aoussat, and T. Reyes, "Systematic literature review of eco-innovation models: Opportunities and recommendations for future research," Journal of Cleaner Production, vol. 149, pp. 1278-1302, Apr. 2017, doi: 10.1016/j.jclepro.2017.02.145.

11. P. M. Clarkson, Y. Li, and G. D. Richardson, "The Market Valuation of Environmental Capital Expenditures by Pulp and Paper Companies," The Accounting Review, vol. 79, no. 2, pp. 329-353, Apr. 2004, doi: 10.2308/accr.2004.79.2.329.

12. S.-Y. Lee, "The effects of green supply chain management on the supplier's performance through social capital accumulation," Supply Chain Management: An International Journal, vol. 20, no. 1, pp. 42-55, Jan. 2015, doi: 10.1108/scm-01-20140009.

13. A. W. H. Yip and N. M. P. Bocken, "Sustainable business model archetypes for the banking industry," Journal of Cleaner Production, vol. 174, pp. 150-169, Feb. 2018, doi: 10.1016/j.jclepro.2017.10.190. 